\title{
Ceiba pentandra (Malvaceae) and associated species: Spiritual Keystone Species of the Neotropics ${ }^{1}$
}

\author{
Marc-Alexandre Tareau, Alexander Greene, Guillaume Odonne, and Damien Davy
}

\begin{abstract}
Among the 18 species included in the Ceiba genus in the Malvaceae (Bombacoideae) family, Ceiba pentandra (L.) Gaertn. is not only the tallest and most widespread but also occupies the most prominent place in Neotropical cosmovisions. In this ethnobotanical review, we compare perceptions and uses of Ceiba and related species across Indigenous and Afro-descendant cultures ranging from the Caribbean to the Argentinian Chaco. Ceiba's widely shared role as axis mundi (particularly in Amazonia), psychopomp, and as a shelter of major forest spirits makes it a perfect example of a Spiritual Keystone Species, a new concept inspired from the concept of Cultural Keystone Species and defined here for the first time.
\end{abstract}

Key words: ethnobotany, Amazonia, Caribbean, lupuna, samauma, mapou, silk-cotton tree, fromager, kapok.

Résumé : Parmi les 18 espèces comprises dans le genre Ceiba, dans la famille des Malvaceae (Bombacoideae), Ceiba pentandra (L.) Gaertn. est non seulement la plus haute et la plus répandue, mais elle occupe également la place la plus importante dans les cosmovisions néotropicales. Dans cette synthèse ethnobotanique, les auteurs comparent les perceptions et les utilisations du Ceiba et des espèces apparentées dans les cultures autochtones et afrodescendantes, allant des Caraïbes au Chaco en Argentine. Le rôle largement partagé du Ceiba en tant qu'axis mundi (particulièrement en Amazonie), psychopompe et refuge des principaux esprits de la forêt en fait un parfait exemple d'espèce clé de voûte spirituelle, un nouveau concept inspiré des espèces clés de voûte culturelles et défini ici pour la première fois. [Traduit par la Rédaction]

Mots-clés : ethnobotanique, Amazonie, Caraïbes, lupuna, samauma, mapou, capoquier, fromager, kapok.

\section{Introduction}

To anyone living or travelling in most parts of the Neotropics or the Caribbean, it is impossible not to notice a majestic tree, its branches crowded with epiphytes and intermingled lianas, bordering Amazonian streams, emerging from distant hills in Caribbean islands, or simply existing in parking lots in urban areas. Among the 16000 or so Amazonian tree species (Ter Steege et al. 2016), one effectively looms above the rest: Ceiba pentandra (L.) Gaertn. This prominent tree from the Malvaceae (Bombacoideae) family is probably the most well-known (and widespread) representative of the Ceiba genus, and it is an important cultural species in the Neotropics. From the perspective of interrogating transversalities and cultural hybridizations across human cultures, this species stands at a meeting point, and we decided to explore in depth the relationships between Amazonian, Central American, and Caribbean cultures and the Ceiba tree. As a consequence of different logics between folk and Linnaean classifications (Berlin 1993), the so called silk-cotton tree that occupies a key place in most cosmovisions ranging from Central America to the Cerrado in Brazil, actually represents a group of several species, some of which are sympatric, and of which the most widespread is Ceiba pentandra. Although this paper mostly focuses on Ceiba pentandra, the others, and their associated local knowledge, are included in this discussion to provide a more global view of the place of these peculiar trees.

The Ceiba genus contains 18 species in the Neotropics, grouped into taxonomic sections Ceiba and Campylanthera (Pezzini et al. 2021). Except for a few Cerrado species, the majority are large trees, often with spines along the trunk and branches, and frequently with large buttresses. Leaves are palmate with three to seven leaflets. Flowers are actinomorphic, with five petals, red, pink, yellow, or

Received 11 May 2021. Accepted 4 July 2021.

M.-A. Tareau, A. Greene, G. Odonne, and D. Davy. Laboratoire Ecologie, Evolution, Interactions des Systèmes Amazoniens, Centre national de la recherche scientifique, Université de Guyane, IFREMER, 97300 Cayenne, French Guiana.

Corresponding author: Guillaume Odonne (email: guillaume.odonne@cnrs.fr).

${ }^{1}$ This paper is part of a Special Issue entitled "Ethnobotany and Ethnopharmacology of the Americas".

(c) 2021 The Author(s). Permission for reuse (free in most cases) can be obtained from copyright.com. 
Fig. 1. Ceiba pentandra emerging from the morning fog along the Lawa River in French Guiana (C) Guillaume Odonne.

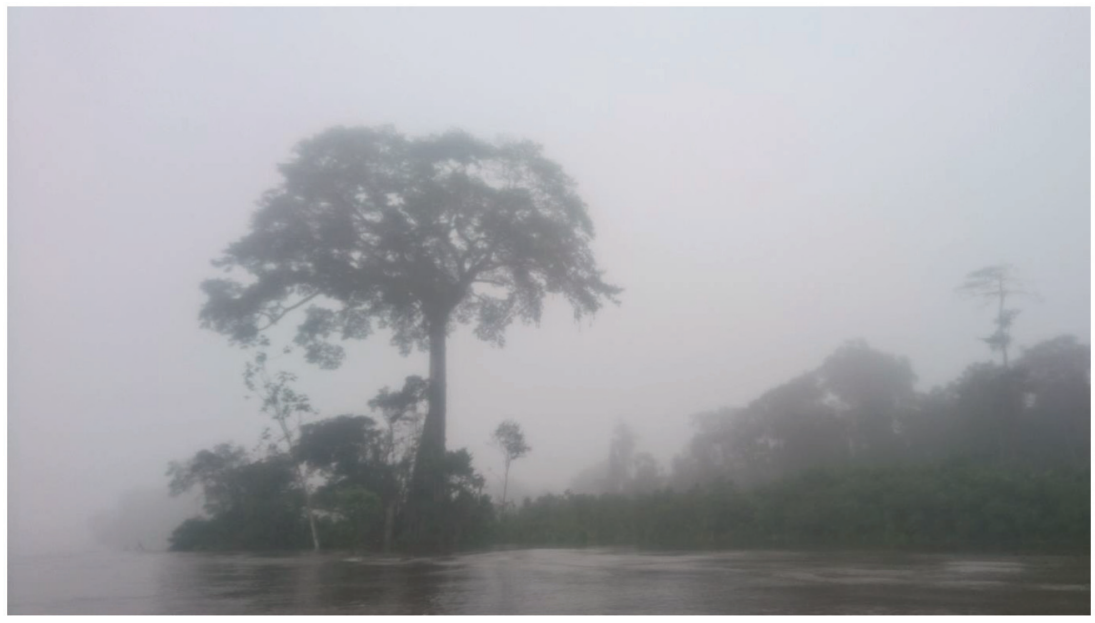

Fig. 2. Distribution maps of the American and African range of Ceiba pentandra (A) and Ceiba genus (B), extracted from Ceiba pentandra (L.) Gaertn. in GBIF Secretariat (2021). GBIF Backbone Taxonomy. Checklist dataset https://doi.org/10.15468/ 39omei accessed via GBIF.org on 31 July 2021.

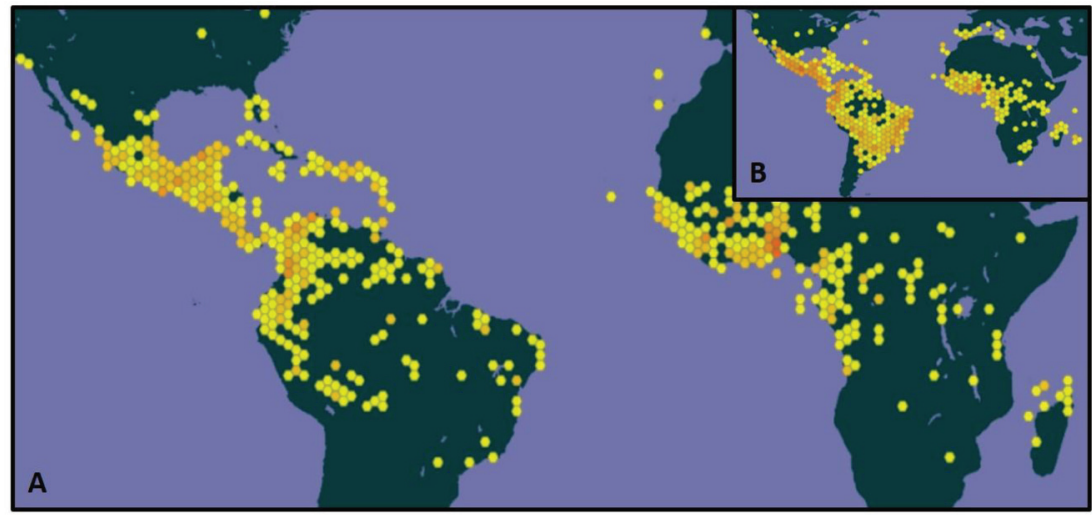

white depending on the species, and from 2 or $3 \mathrm{~cm}$ to $15 \mathrm{~cm}$. Ceiba pentandra is the tallest, frequently emerging above the canopy (up to $70 \mathrm{~m}$ high) (Fig. 1), and developing large buttresses bearing conical prickles. Flowers are pentamerous, small $(2-3 \mathrm{~cm})$, white, and its seven-foliolate leaves are glabrous. The fruit is a capsule (12-24 cm long), containing seeds surrounded by long, wooly, non-wettable hairs called kapok (Dick et al. 2007; Mori et al. 2002). Ceiba spp. range from seasonally dry tropical forests to tropical forests, and from Mexico (North) to Argentina (South) (Fig. 2). Ceiba lupuna P.E.Gibbs \& Semir is the only species restricted to rain forests. Ceiba pentandra, Ceiba samauma (Mart. \& Zucc.) K.Schum., and Ceiba speciosa (A.St.-Hil.) Ravenna are mostly present in rain forests, whereas the other species are more widespread in seasonally dry forests (Pezzini et al. 2021). Ceiba pentandra is also naturally present in equatorial Africa and naturalized in all the humid tropics after human introduction (https://www. gbif.org/species/5406697) - it originated from the Neotropics and its seeds probably dispersed to Africa by floating over the Atlantic Ocean (Dick et al. 2007).
Questioning inhabitants about these trees, one rapidly understands that they bear something unique. We first noticed this through years of fieldwork in collaboration with Amazonian and Caribbean peoples, and as we started reviewing the literature about Ceiba spp., it became clear that this species represents a very good example, in this vast region of the world, of a Cultural Keystone Species (Garibaldi and Turner 2004). But unlike most Keystone Species, Ceiba is not an edible plant and is minimally used in medicine, technology, and craft (although kapok fibers have an undeniable technical and economic interest). To better explain the cultural centrality of Ceiba spp., we thus decided to develop the concept of a Spiritual Keystone Species to describe the importance of the silk-cotton tree in Neotropical cosmovisions.

\section{Materials and methods}

A thorough review of our personal Neotropical anthropological and ethnobotanical literature was conducted by searching for all the Linnaean names related 
to Ceiba (Chorisia, Bombax etc.), as well as the most common folk names (fromager, lupuna, mapou, paineira, samaúma etc.). Additional literature was gathered from Scopus, J-Stor, and Google Scholar with the same keywords. To this review of the literature, we added notes taken during our own field observations, mostly in Amazonia, the Guiana Shield, and the Caribbean. Linnean names were updated according to APG IV (The Angiosperm Phylogeny Group 2016) via the Taxonomic Name Resolution Service (Boyle et al. 2013).

\section{Results and discussion}

A founding and shamanic tree among Indigenous cultures From Central America to the Argentinian Chaco, the genus Ceiba shares a singular place in cosmovisions. The firsts synthetic writings on Indigenous cultures of the Guiana Shield by authors such as Roth (1915) and de Goeje (1943) showed the cultural importance of this tree. For the Akawaio, Makusi, and Arawak from Guyana, all beings were created from pieces of Ceiba wood or bark that were thrown from the top of a large tree (on land or in the water) by a demiurge, thus creating birds, terrestrial and aquatic beings, as well as men and women (de Goeje 1943; Roth 1915). In contrast, the Urubu Ka'apor from Brazil believe that the nonIndigenous people were those created from its wood, whereas they were carved from Handroanthus serratifolius (Vahl) S.O.Grose (Balée 1994). One of the formative clans of the Wayãpi from French Guiana, the "kumakapisuke" ("old beetle larva of the Ceiba tree" in English) are the offspring of an incestuous couple, itself born of insect larvae found in the trunk of a rotting Ceiba (Grenand 1989). The classic period Maya of Mesoamerica and their modern descendants give this tree a central place in their mythology (Freidel et al. 1993; Schele and Freidel 1990). Indeed, "yakché" ("the green tree" in English) is the primordial tree, the axis mundi of the Mayan world, passing through the seven heavens above the Earth and allowing the spirits of the dead to pass from one world to the next to finally reach the eternal abode (Tozzer 1907). As exemplified by Cano and Hellmuth (2008), Guatemalan murals and ceramics from the classic Mayan period widely feature Ceiba trees, and pre-Columbian Mayan incense burners were often represented with Ceiba prickles, probably associating this species to religious and (or) spiritual aspects (Zidar and Elisens 2009). The Hatx Winik, Lacandones from Chiapas, also see Ceiba as the pillar of the world, the support of the vault of heaven, and the dwelling place of the tree spirits (Pérez 2005).

While in the Chamacoco's view of the universe, Ceiba insignis (Kunth) P.E.Gibbs \& Semir (known in Paraguay as "pallo borracho") is a cosmic tree linking the Earth and the sky (Sequera and Gangui 2011), Lévi-Strauss highlighted in the second volume of his mythological masterpieces that the "yuchan" of the Matako and Chulupies from the Paraguayan and Argentinean Chaco "once contained all the water of the world in its bulging trunk and where men obtained fish from one end of the year to the other" (Lévi-Strauss 2009, p. 86). Their Chorote neighbors also believe that all the water in the world and all the fish come from the trunk of the Ceiba chodatii (Hassl.) Ravenna (Scarpa 2007). Among the Peruvian Yagua, the lupuna (possibly Ceiba lupuna) is the water tree and the symbol of the axis of the world (Chaumeil 2000). A Yagua myth tells how this giant tree was cut down by the two mythical heroes, and as it fell, created the Amazon (the artery of the world whose meanders correspond to the sinuous contours of the trunk and branches), all of its water emptying to form this great river (Chaumeil 2000). Other versions of this myth are found in Amazonia and Gomez Gruber (1997) reports that, among the Tikuna, in the beginning only night existed because a large Ceiba obstructed the world and prevented light from entering it. The primordial brothers tried to remove it without success. They called for help from all the animals in the forest but only a small squirrel succeeded in felling the tree so that light could finally appear. The trunk formed the Rio Solimões and its branches the other rivers and creeks. To prevent the tree from growing back, the brothers put a giant turtle on the stump to graze on the new shoots. A butterfly took the heart of the tree, which was still beating, and gave it to an agouti that buried it. From the heart grew an umari tree (Poraqueiba sericea Tul. or Poraqueiba paraensis Ducke), which gave birth to the first woman who then married one of the two brothers. Relation to water is also evident for the Kali'na of the Guiana Shield, where the mythical anaconda Alamari, while lying in the canopy of a Ceiba, was so heavy that it broke the branches under it and fell into the river and became the water spirit Okoyumo (Ahlbrinck 1931). For the Huaorani from Ecuador, the Ceiba is the primordial tree providing shade, food, and shelter, where all the beings dwelled in the beginning. This tree was bound with a large vine but a little squirrel cut it so that the "Amazon Basin was born from the fallen giant tree, and the many species of fish from its leaves" (Rival 1999, p. 361). Among the Kogi from Colombia: "When the ninth world, the highest world, was being formed, an immense Ceiba tree began to emerge from the pristine sea and around this cosmic axis the four divine brothers built the first temple and called it "alnáua". The Ceiba tree is called "ululá" or is personified by the name of the mythical Máma Zinkala. It was the first tree of Creation... A vertical line passing through the tip of the roof, through the centre of the floor and the nadir which - in this case - is the apex of the invisible inverse roof, constitutes the cosmic axis, identified with the spindle rod, with the great Ceiba of Creation, or with the central pole that the Mother placed in the centre of the snow-capped mountains" (Reichel-Dolmatoff 1975, p. 204). The Baniwa of Uaupes share this worldview of a 
giant Ceiba passing through the different worlds stacked on top of each other, inhabited by different beings (Wright 2020). Lévi-Strauss (2009) points out that the Mocovi and the Bororo believe the Milky Way to be the ashes of the tree of the world after it was burned down. This is similar to the Wayana cosmovision - their founding demiurge, Kuyuli, and his companion burned a gigantic Ceiba whose ashes became the Milky Way, which means in Wayana "the place where the Ceiba was burned" (Chapuis and Rivière 2003, p. 171). Wayana Shamans travel the Milky Way during trance (de Goeje 1943).

Many Amazonian cultures consider this tree to be the vehicle for Shamans to move through the different strata of the world. Thus, as do the Baniwa, the Wayãpi of French Guiana consider Ceiba to be the Shamans' ladder used to climb and meet their spirit allies (Grenand et al. 2004). Indeed, for them, this tree is inhabited by a "kumakaya", a very powerful jaguar spirit that only the most powerful Shamans can domesticate (Grenand 1980). The spirits or metahumans - to use the term proposed by Sahlins (2019) with regard to Descola's (2005) animist ontological scheme - or the mother of this tree, are powerful and linked to the masters of the forest. Among the Kali'na, dwelling from French Guiana to Venezuela, the Ceiba is considered the "wewe yumu", the father or master of the trees (de Goeje 1943). Of the five types of Shamans, which are defined according to the plant guiding their initiation, there are "takini" (Brosimum acutifolium Huber), chile (Capsicum annuum L.), tobacco (Nicotiana tabacum L.), "kwasini” (Ficus spp.), and "kumaka" Shamans (Ceiba pentandra). The spirits inhabiting "kumaka", like those of the "kwasini", are both beneficial and maleficent, unlike the first three types that are only beneficial. Moreover, according to Gillin (1936), the Ceiba tree is distinguished from other trees by the fact that it harbors many spirits including a particular being that lives only in this tree, the "kumaka akïri". The number of spirits hosted by it is also the reason for its gigantic size and implies that it must not be felled. If someone tries to fell it, the axe will inevitably break. And if in the end they finally manage to cut the tree, the spirits that would escape from it will never be appeased. Ahlbrinck (1931) tells a Kali'na myth about how a nine-year-old boy was attracted by the spirit of the "kumaka" and was initiated. He became a very powerful Shaman who was only called for when a person died as he could resurrect them, whereas other Shamans were powerless. The boy used to sleep in this tree and came back to the people only when someone had died.

Ceiba is also considered a link with other spirit plants; for the Kali'na, the anaconda Alamari, who lived at the top of a Ceiba, was so gigantic that it completely covered the branches of this giant tree. It hunted without leaving its tree, attracting game with its spells. One day, a young girl collected some white clay at the foot of the
Ceiba and smeared it on her garters to whiten them, but it was Alamari's excrement so he became her husband. The villagers opposed this union, set a trap for Alamari, and burned him alive. From his ashes grew the charms "tulala" (Caladium spp.) (Ahlbrinck 1931). Alamari is considered the spirit of this tree (and that of the "takini") and controls all Ceiba and other trees' spirits (de Goeje 1943). The Teko from French Guiana similarly consider that if the remains of a giant otter, "tsololo" (Pteronura brasiliensis), are buried at the foot of a "kubaka" (Ceiba pentandra), all sorts of medicinal plants will grow on its rotting body (Navet 2008). They tell that "in the "kubaka", there can be good and bad spirits. When the tree is beautiful and clean underneath, it means that there are "kaluwat" (good spirits) but when the tree is not beautiful and is dirty underneath, it means that it is inhabited by "baskilili" and "gulupi" (bad spirits)".

For the Tikuna, the master of this tree is the master of the forest or Curupira, Ngo'o in Tikuna (Matarezio Filho 2015). The spirit of the Ceiba is considered to have a black color among the Yagua, Kali'na, and Teko. The Palikur from French Guiana and Brazil use a bath of Ceiba bark during the initiation of Shamans (F. Renoux, personal communication). Similarly, the Yagua make a shamanic initiation cigar from its bark (Chaumeil 2000). For the "curanderos" from Huancabamba (Peru), Coleus sp. mixed with Ceiba pentandra, "higiron" (an unidentified species, probably a Ficus sp.), latex of "lechero" (Euphorbia sp.), chili pepper (Capsicum annuum), salt, alcohol, and holy water can kill an enemy (De Feo 1992), whereas the Peruvians of Loreto consider its bark a shamanic poison (Roumy et al. 2020). Among the Yanomami, the spirit of the Ceiba is invoked during shamanic treatments to scare away evil spirits, and evil substances are dispersed via its cottony fibers (Albert and Miliken 2009). Bennett et al. (2002) describe an Aguaruna myth: "A person clears the plants from the base of a Mente tree (Bombacaeae spp.) and then drinks green tobacco juice until he becomes intoxicated. During a storm the "wiakuch" or soul of the tree comes. "Wiakuch" gives the person magical darts that enable him to become a shaman". Ese-Eja from Peru consider it a "teacher plant" in ayahuasca shamanism and "sorcery with Ceiba spp. causes the swelling of the victim, a condition which on one case was medically diagnosed by hospital workers as water retention through kidney malfunction" (Alexiades 1999).

The Shipibo also attribute a very powerful spirit to Ceiba, which is associated with ayahuasca and brings visions (Saavedra 2006). When a Shipibo wants to become a Shaman and wishes to know the spirit of this tree, he drinks the bark with tobacco in the morning for six to eight months (Childs 2012). Among the Chorote of Argentina and Paraguay, a shamanic chant linked to the Ceiba tree allows one to meet the drinking water accumulated inside its trunk, and songs also allow the 
Shaman to use the trunk as a "jail of souls" (Scarpa 2007). Among the Amazonian Mestizo populations of Peru, the spirit of this tree is considered very dangerous and acts as a sorcerer and can kill people who do not follow the required recommendations (Luna 1986). This author states that among the Shipibo of Peru, the spirit of this tree is the supreme spirit or chief of the forest and of the spirits of the other trees, and also the chief spirit of the Shipibo Shaman (Saavedra 2006). It is considered to be the rain tree, and rituals are held near it to beg for rain, further reinforcing the link between Ceiba and water. Among the Shipibo and Conibo, Tournon (1990) says that the Ceiba can "cutipar", meaning if a father cuts the tree down his son will be bewitched and suffer from swelling of the belly. The remedy consists of bathing in a decoction of bark from the same tree. Among the Tacana of Bolivia, Ceiba's spirits can cause "mal viento" (DeWalt et al. 1999). The Sumu Ulwa of Honduras also believe that a powerful spirit inhabits this tree (Coe and Anderson 1999). The Shawi in the Peruvian Amazon fear this tree because of the spirits it hosts. They are said to turn around its canopy at night, whistling, and it is advised not to stay nearby. Among the Yagua of Peru, the mother of the Ceiba is very powerful and the Shamans use it to deprive victims of their vital principles and drive them mad by subtracting their spirit and causing their stomach to swell. This mother of the Ceiba has either the form of a snake (like the Kali'na), an earthworm, or a human, and its color is black (Chaumeil 2000).

Moreover, the ability of this tree to move is regularly mentioned in the literature. The Arawak of Guyana believe that it moves nightly and returns to its place afterwards, this ability being due to the spirit that inhabits it (Roth 1915). For Dance (1881), the guardian spirit of this tree "walks around the tree at mid-day and at mid-night". According to the Yaminawa, the Ceiba is the house of Xuba, a strong and aggressive being that can cause illness to whoever passes by or whoever tries to cut it down without taking the proper precautions, and Xuba is especially harmful to parents with newborn children as the spirit of the tree can borrow the soul of the child (Gillin 2014). Among the Miskito, dwelling from Honduras to Nicaragua, the Ceiba spirit called Sisin Dawanka can offer individuals wealth, success with members of the opposite sex, misfortune for their enemies, and so on: the supplicant has only to approach a Ceiba tree where the "dawanka" is supposed to live and a door will open in the tree to admit him or her. At that moment the deal begins. The "dawanka" may grant the supplicant a major request but usually asks for payment. For example, he or she may grant the supplicant his or her wish with the understanding that he or she will later claim his or her first child, an aspect of the contract that the human participant, in his or her greed, may not take into account. Later, the "dawanka" may return to claim what he or she considers to be his or hers by right of the contract" (Jamieson 1970). For the Colombian Siona, Ceiba is the most dangerous tree. It has three different classes of "huati" ("invisible spirits" in English): those that live under the roots and scare people by giving them diseases; those that live in the trunk and are located in the buttresses, which sometimes appear to hunters to make them get lost; and those that live in the foliage, whose long tongues hang down to catch men passing underneath. If caught, the person will suffer from a disease that causes the tongue to hang out of the mouth. It is therefore not advisable to pass alone under a Ceiba but if you must, you should whistle and smoke a cigarette to protect yourself (Langdon 2014). The Kalinago from La Dominique believe that Ceiba shelters spirits that might become angered if disturbed (Hodge and Taylor 1957).

Along with being considered a Shaman's spirit ally, the Ceiba is connected to death and is sometimes perceived as a psychopomp tree. The Chacobo believe that the souls of the dead reside in the trunk of the Ceiba (Erikson 2014). Among the Maya (Landa), the souls of the dead go to the great green tree ("yakché") to enjoy the coolness of the shady branches, under which they enjoy eternal rest (de Goeje 1943). The Wayana, living in Brazil, French Guiana, and Suriname, believe that after death the soul reaches a gigantic tree - the Trios and Guarayos believe this tree is none other than the Ceiba (de Goeje 1943).

\section{A symbolic species among Afro descendants}

Interestingly, Ceiba pentandra is also omnipresent in the Afro-American magico-religious universe (Nossin 2019). As Hurbon (1940-1972) pointed out, the strong permanence in Haitian voodoo of the attribution of magical properties to the silk-cotton tree is undoubtedly the result of a resonance between beliefs of African origin (the tree is sacred in many West African cultures; Burkill 1995) and the cultural importance of this same species within many Indigenous American cultures (see previous parts). The convergence of these analogous belief systems must have contributed not only to the reinforcement of those of the enslaved Africans and their descendants but also to an interculturalization effect (Tareau 2019) that has given rise to reinvented practices that do not appear to be the simple survival of African rituals (Price and Mintz 2013).

In Cuba, Ceiba pentandra is also a major host tree for several "orishas" (including Aggayù, Babà, Iroko, Obatalà, Oddùa, Ogùn, Oko, Olofi, Shangó, Yemayà) and is therefore the object of a particularly important devotion among a large part of the population following AfroCuban cults. According to a widespread syncretic belief in Cuba, which also provides an interesting Christian explanation to the popular sacralization of the tree, the Virgin Mary and the infant Jesus took refuge in a cavity of a silk-cotton tree that then closed and grew thorns to 
Fig. 3. Ceiba pentandra tree used for voodoo ceremonies in Cayenne, French Guiana. (C) Marc-Alexandre Tareau. [Colour online.]

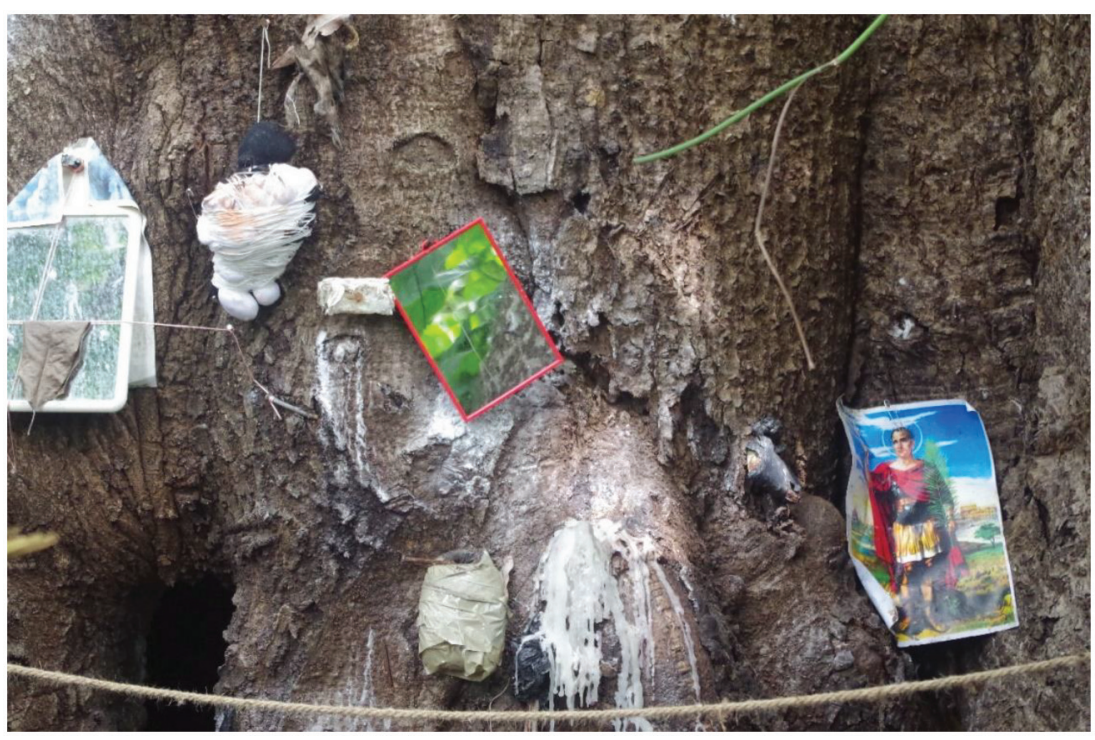

protect them (Pesoutova 2019). According to Cabrera (2003), "the dead, the ancestors, the African "saints" of all the African nations that came to Cuba and the Catholic saints go to this tree and inhabit it permanently" (p. 166). The tree, which in Cuba is also never cut down, is called "iroko" by the Afro-Cubans, in memory of the tree revered throughout the Guinea coast, Milicia excelsa (Welw.) C.C.Berg, also called “iroko" in western Africa (Quiroz 2015; Quiroz and van Andel 2018). In addition, in the mythological representations of Afro-Cuban Santeria, Iroko is also the name given to an important "orisha" who is believed to live in the trunk of the Ceiba tree in the company of his wife Aboman (Cabrera 2003).

Called "mapou" or "pye mapou”, probably an apocope of the common Kongo name "mapouata" (Nossin 2019, citing Durand and Logossah 2011) in Haitian Creole, Ceiba is arguably the most revered plant species in Haitian voodoo (Hurbon 1940-1972). Indeed, this tree serves as the residence ("repozwa" or "kay lwa" in Haitian Creole) of several spirits ("lwa") of the Haitian voodoo pantheon, particularly those of the Gede (Tarter 2015), who are the "lwa" of death (Marcelin and Métraux 1947). According to several testimonies collected from Haitian voodooists, it is also home to the "lwa" called Agarou, who is the god of the wind and the storm, Loko (probably by borrowing another vernacular name of the species M. excelsa, "loko" in Fon), who is the god of trees and forest, and Erzili, who is the goddess of fertility (Marcelin and Métraux 1947). For this reason, it regularly receives offerings and libations, and scarves, candles, and images in the symbolic colors of the "lwa" associated with Ceiba are regularly attached to its branches or trunk (Fig. 3). Luck baths ("ben chans") are commonly taken near the tree by practitioners who hope to attract the favor of the spirits it shelters. In addition, its status as a sacred tree means that it is almost never cut down for fear of divine reprisals that could fall on those who commit this act, unanimously considered as sacrilege (Séverin 2002). A Haitian man residing in Cayenne, French Guiana explained that "mapou is the cathedral of voodoo. The Catholics put candles in the chapels, we put ours on its trunk. So cutting down a mapou tree, for a voodooist, is like destroying a church for a Christian. It is a serious $\sin$ ".

Among the Aluku Maroons of French Guiana, the seedling is used to strengthen babies (Fleury 1991). The spirits related to the supreme god Papa Gadu (or Voodun) as well as Ampuku, the spirit of the forest, reside in this tree called "kankantii" (by deformation of the English "cotton tree") and may be incarnated in the red-tailed boa (Boa constrictor, which is called "daguwe", from the Dahomean "dãgbe”, an Ewe-Fon word also used to designate a sacred snake; Herskovits and Herskovits 1936). However, unlike the Caribbean and French Guianese Creoles who do not hesitate to plant it (some silk-cotton trees are even enchanted - "monté" in French Caribbean Creole) to protect a plot of land against evil spirits and promote their owner's luck (Benoît 2000; Vilayleck 2002), the species is avoided around the homes of the Maroons. Although, paradoxically, several Maroon villages are characterized by a giant silk-cotton tree overhanging and "protecting" them, French Guianese Maroons believe that it can carry evil entities. Thus, we can probably argue - to use the image formulated by Price and Mintz (2013) - that the same symbolic container (the sacralization of Ceiba pentandra) has spread within several Afro-descendant cultural groups, but that their particular histories have forged different contents (the beneficial or maleficent "nature" of this species). In any case, as early as 1890, the explorer- 
Fig. 4. A Ndjuka maroon healing house (“Obia osu”) under a Ceiba pentandra in 2004 close to the Maroni River. (C) Damien Davy. [Colour online.]

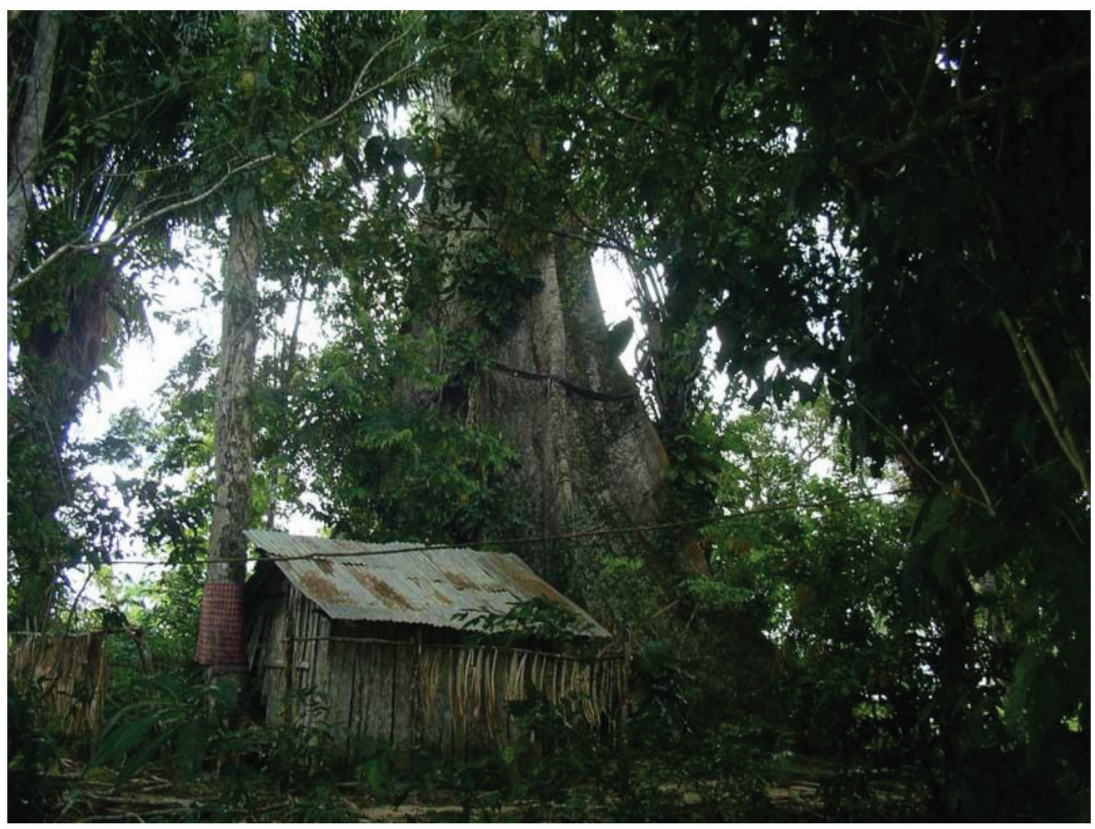

missionary Verschuur reported the "kankantii" tree as the most venerated tree of the Maroons of French Guiana (Verschuur 1894) and contemporary testimonies confirm this idea: "the "kankantii" is like a lightning rod, it attracts evil spirits. It shelters both the good and the bad ones... the Ampuku spirit lives in the big "kankantii", that's why we don't cut it down or burn it. We put beers at its foot for them. It is also where we make music for the "obia" [spirits]. People also bathe under the "kankantii" for good luck, but if you use its leaves or bark to make remedies, you have to pay him with beer and rum. If someone is possessed, they are bathed under the "kankantii" so that the Ampuku spirit in the person returns home", explained a Saamaka man living in Matoury, French Guiana.

Some healing houses are nevertheless located at the foot of large silk-cotton trees to allow the medico-magical rituals to be more effective thanks to the nearby deities present in the tree (Fig. 4).

In the other Creole societies of the Caribbean and the Guiana Shield where Afro-descendant religious heritage is less institutionalized than in the previous cases, some survivals must nevertheless draw our attention to the persistence of a certain religiosity around Ceiba pentandra. This tree is a dwelling place for African spirits in Venezuela (Pollak-Eltz 1972). In Martinique (Nossin 2019; Vilayleck 2002), Guadeloupe (Benoît 2000), French Guiana (Ribal-Rilos 2004), Suriname (van Andel 2010; van Andel and Ruysschaert 2014) and in the Dominican Republic (Pesoutova 2019), it would not occur to an inhabitant to cut down this tree, which allows it to survive in the urban space where it sometimes remains isolated amongst buildings (Fig. 5).
In the same way, many people continue to venerate the tree in a clandestine way, talking to it to ask for advice or courage or lighting a candle at its foot in honor of the deceased or in search of luck. The Martinican poet Césaire himself regularly visited a silk-cotton tree, the only tree to survive Mount Pelée's eruption in 1902 (Nossin 2019). This devotion is, however, mixed with fear as Ceiba pentandra is considered "the devil's tree par excellence", housing potentially dangerous spirits such as "soukouyans" or "soukliyan" (flying entities that, like vampires, suck the blood of their victims) in the French West Indies (Leti 2000) or "jumbies" and (or) "duppies" in Jamaica (Corzani 1994; Keegan and Carlson 2008).

If it is true that these magical attributes are sometimes transversal to the shamanistic properties mentioned previously within many Amerindian communities, they are also linked to uses found in Africa. Indeed, Burkill notes that it is the most important fetish tree in many West African cultures and that, for example, in the Sudanian region it is considered to be inhabited by the divine python (Burkill 1995). Herskovits also notes that in the former Dahomey, the silk-cotton trees are revered because the souls of ancestors have taken their residence in them, likewise among the Ndjuka from Suriname (Herskovits and Herskovits 1936).

\section{Medicinal uses}

Alongside the properties of Ceiba in shamanistic healing, some phytotherapeutical uses, although much less numerous, can also be noted throughout its distribution. Among these, the most common are as a diuretic, analgesic, or for healing wounds. 
Fig. 5. A preserved silk-cotton tree in Cayenne. (C) Marc-Alexandre Tareau. [Colour online.]

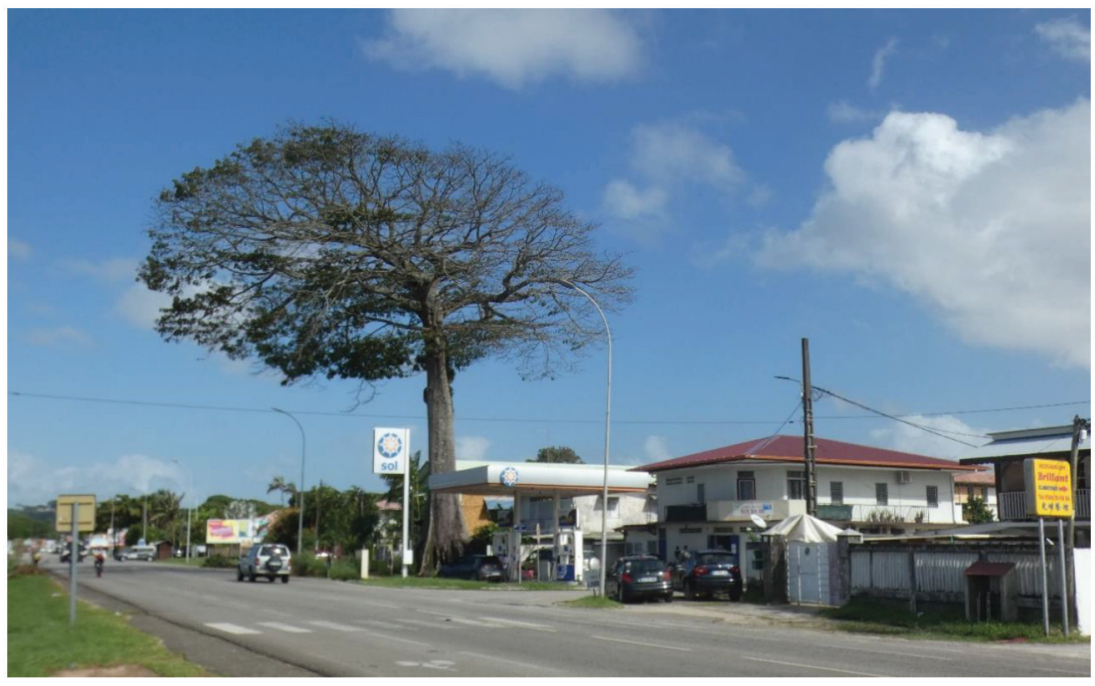

The species is used for waist pains and as a diuretic among the Pilaga of Chaco (Filipov 1994). Among the Ayoreo, from Chaco as well, the plant is employed to cure open wounds (Renshaw 2006). Some observation of its use against leishmanial external lesions were made among the Wayãpi (Odonne et al. 2011) and the Ashuar (Giovannini 2015) who apply the ground bark directly. This last application is also noted among the Kallawaya in the treatment of tetanic wounds (Girault 1984).

Among the latter community, the decoction of the flowers is applied to the temples and forehead to treat headaches (Girault 1984). Similarly, the infusion of flowers is drunk to relieve headaches in Venezuela (Delascio-Chitty 1985), and in Guadeloupe when a child is teething, the child is given a mouthwash with a decoction of Ceiba leaves mixed with soursop leaves (Annona muricata L.) and Bidens sp. leaves (Bougerol 1993). In Martinique, ground fresh leaves are used in capillary massages for baldness, and the root bark is drunk as a depurative decoction (Ouensanga 1983). Among the Amazonian "ribeirinhos", the sap is a remedy against conjunctivitis and the bark is used as an antidiarrheal and diuretic (Silva et al. 1977). Finally, in the Saint Lucian community of French Guiana, the ground bark of the trunk is used in the composition of a plaster used to heal broken limbs (Tareau 2019).

The astringent mucilage contained in the bark is also used in other parts of the world. For example, a bark decoction is used as mouthwash in Senegal and Liberia, and for febrifuge in Nigeria (Burkill 1995).

\section{Technical uses}

One of the best known technical uses of Ceiba pentandra in Amazonia is the use of its cottony stuffing or kapok a term derived via the Dutch from the Malay "kapuq", which refers to the fibers surrounding the seeds (Couplan
2000). Indeed, among all Amazonian peoples using blowpipes for hunting or warfare, these cottony fibers are used as a stuffing attached to blowgun darts to form a pressure seal and airfoil. This use was observed among many cultural groups: Siona (Vickers and Plowman 1984), Matis (Erikson 1996), Huaorani (Davis and Yost 1983), Shuar (Bennett et al. 2002), Yagua (Chaumeil 2000), Nikak (Mahecha and Franky 2013), etc. Etymologically, this use can be identified in the Shuar word for Ceiba, "wampuish", which stems from the term "wampúch" and means "little weigh" (Bennett et al. 2002). It can also be identified in the Siona word "huo yui", which means "blowgun cotton" (Vickers and Plowman 1984), and in the English common name for Ceiba, silk-cotton tree. Siona people used the seed as a fish bait (Vickers and Plowman 1984). Kapok was used industrially until after the Second World War because it was considered to be high quality, insulating, and moisture resistant (Pio Correa 1984; Zeven 1969). Kapok has since been dethroned by synthetic fibres, though the world's leading producers of kapok are still Indonesia and Thailand, which produced almost all the world's kapok with 101300 tonnes in $2013^{2}$. Before the Second World War, the kapok tree was an important commercial crop because its fibers were used extensively in life-jackets and life-belts, in clothing for aviation, as a mattress and cushion-filling material, and in noise insulation for aircraft (Zeven 1969). In Brazil, as in Guyana and Mexico, kapok was used for pillows and mattresses (Cano and Hellmuth 2008; Silva et al.1977; van Andel 2000).

Another important and nearly universal use is that of its wood, which is particularly soft and light. Before the spread of mechanical tools, this wood was widely used to make large canoes (in former Dahomey, this tree was

\footnotetext{
${ }^{2}$ https://knoema.com/data/agriculture-indicators-production+kapok
} 
known as "the tree of the canoes"; Burkill 1995). PreColumbian peoples, in the absence of iron tools until 1492, preferred easy-to-carve wood for their dugout canoes, and it is sometimes asserted that the West Indies were settled from Venezuela using Ceiba canoes (Bernand 2019). This use is found among the Taino and the Caribs from Martinique (Breton 1665), but also among contemporary Jamaicans, the Tsimane (Reyes-García 2001), the Payas of Honduras (Lentz 1993), and the Maya of Yucatan (Cano and Hellmuth 2008). The Warao used this tree to make canoes that could carry up to 80 people (Roth 1915). One of their myths, the story of Haburi (their civilizing hero), tells how he built a canoe out of wax, then out of clay, then out of different kinds of wood, but all these canoes were stolen by ducks and only the one made out of Ceiba was not stolen (Roth 1915). Puerto Rico even made the Ceiba its national tree in memory of its importance as a material for dugout canoes (Shearn 2020). Some groups such as the Yanomami made containers for their plantain puree (an important preparation in death ceremonies, the use of Ceiba pentandra may not be coincidental) (Albert and Miliken 2009) and among the Piaroa, these canoes were used for cassava beer in Jurupari ceremonies (Mansutti Rodríguez 2019). The Shuar also used the buttresses of the Ceiba to make shields (Bennett et al.2002). Uniquely, the Wayana use its buttresses to carve their wheelof-the-ceiling or "maluwana", a painted wooden circle attached at the top of their round collective house, the "tukushipan". This "maluwana", decorated around its perimeter with triangles representing the thorns of the trunk of Ceiba pentandra, is painted black and numerous monstrous and metamorphic aquatic beings, the "ipo", are drawn on it (Duin 2009). This object is culturally important because it protects the building on which it is placed. Nowadays, these "maluwana", which are still used on "tukushipan", are the object of a growing art trade and provide a living for several craftsmen.

Its wood, considered good for cellulose, was overexploited in Peru in the 1970s and 1980s to make plywood: five factories were dedicated to plywood production in the late 1970s (Gentry and Vasquez 1988). Moreover, Descola (1996) mentions that the Ashuar have long sold Ceiba driftwood logs to the Spanish.

\section{What makes Ceiba magical?}

In regards to Amazonian cultures, there is an obvious and direct relationship between kapok, hunting darts, and spiritually propelled shamanic darts, allowing anthropologists to draw attention to the agency of the fibers of this culturally significant tree (Chaumeil 2000). The sharp, spiny thorns on its lower trunk can be compared with shamanic darts and its size can be correlated with the enormous power of it spirit. The inhabitants of the Lesser Antilles believe that the silk-cotton tree is the refuge of the "volan" or "soukouyans", vampire-like flying evil creatures that would turn around the top of the tree during full moon nights (Leti 2000). This description is perhaps due to the numerous bats that contribute to the pollination process of the species (Gribel et al. 1999; Lobo et al. 2005).

Several traits of the Ceiba are evoked within African American cultures to attest to the magical nature of this tree. According to van Andel et al. (2013), in the emic representations of the Ndjuka from Suriname and French Guiana, one of the proofs of its divine power is that many animals and plants (epiphytes) find refuge on its branches. Moomou (2013, p. 422) notes that "the "kankantii" is also feared because of its gigantism. Indeed, it is the largest tree in the forest, which. . is necessarily home to deities". This last point is also stressed by Tarter (2015) in Haiti, where the physical enormity of this species, as well as its immutability, are singularities often designated to explain its magical character. Moreover, its capacity to remain immutable through time would also explain its resistance to climatic hazards (hurricanes, lightning), which according to Cabrera (2003), is regularly mentioned by Afro-Cubans to justify the mystical properties commonly attributed to it. Furthermore, as in many Indigenous cultures, it appears that several Afro-descendant communities consider the silk-cotton tree as a sort of mediating antenna between humans and the gods (Small and Small 2003).

Métraux notes that in Haiti, the large "mapou" move at night to visit each other and terrorize travelers on the roads, with their branches like long arms (Marcelin and Métraux 1947, p. 144), a belief also found in Jamaica in the 19th century (Rashford 1985). This point highlights one of the characteristics of the notion of "tree agency", which was developed by Jones and Cloke (2008), namely the recognition of anthropomorphic qualities in Ceiba trees.

Finally, one of the most common biocultural justifications for the magical power widely devoted to this plant species in African-American societies is the regular presence of springs or streams where it grows (Séverin 2002). Indeed, generally preferring alluvial soils (Small and Small 2003), Ceiba pentandra is often accompanied by this vital and fundamentally determining element in the cultural designation of plants considered magical (Nossin 2019; van Andel et al. 2013). Moreover, the medicomagical therapy of Haitian voodoo recommends taking protective plant baths in the streams that flow near the "mapou" (Tareau 2019).

As Roe wrote, it "is an "anomalous" tree because its trunk is bulbous, rather than straight, and hollow rather than solid. Moreover, it is soft, rather than hard, and light in weight, rather than heavy, the normal characteristics of trees. It is also significant that it bears water in its interior. The whole tree is like some sort of curious fruit with its aqueous interior and bulbous shape” (Roe 1982, p. 141). 


\section{Defining Spiritual Keystone Species}

The widespread significance of Ceiba pentandra among Amazonian, Caribbean, and West African peoples, and the strong correlations and overlaps in beliefs and practices connected to it (sheltering spirits, shamanic potency, mythic snake, origin of the waters, creation) can be understood as an expression of the world tree or axis mundi concept as expressed by Eliade (1958). The tree at the center of the world, which connects the upper and lower realms and defines the vertical dimension of space with its trunk and the horizontal dimension with its roots and branches, is a foundational concept for many cultures and has been associated with a wide range of different tree species. The process by which the symbolic world tree is identified with a Linnean species is naturally dynamic, as it is subject to processes of cultural exchange, transformation, and hybridization. For example Yggdrasil, the world tree of the Norse, is generally identified as an ash tree (Fraxinus excelsior L.) but sometimes also with the yew (Taxus baccata L.) (Hooke 2012). The dynamic nature of the process of sacralization of specific trees is particularly notable with Ceiba pentandra, in part because of the application of the common name ceiba to the related Bombax ceiba L., which is also a sacred species in its natural range in Asia (Fowler 2003; Jain et al. 2009). This appears to have facilitated the sacralization of Ceiba pentandra in areas where the two species both occur, for instance in India (Chauhan and Chauhan 2019), through a process of cultural hybridization similar to that which has taken place in Amazonia and the Caribbean.

The physical and mythological centrality of species like Ceiba pentandra and Bombax ceiba make them perfect candidates for Cultural Keystone Species as defined by Garibaldi and Turner according to a set of six core criteria (Garibaldi and Turner 2004). Ceiba trees meet four of these criteria remarkably well (intensity and multiplicity of use, linguistic evidence, role in rituals, persistence in cultural memory), so it is not surprising that Ceiba pentandra is sometimes identified as flagship species (Anderson 1997; Bowen-Jones and Entwistle 2002). However, Ceiba trees do not match well with the criteria of "unique position within a culture/irreplaceability" because of the fluidity of belief and practice in relation to the different Ceiba species. They also do not play a central economic role in most cultures to which they are important, so the degree that they "contribute to resource acquisition" is minimal or at least irregular.

The concept of Cultural Keystone Species was originally an adaptation (Platten and Henfrey 2009) of the Keystone Species concept of ecology (Paine 1969). It has been applied to a diverse range of culturally important flora and fauna, from rice in the Phillipines (Zapico et al. 2020) to bears in Canada (Clark et al. 2021), echidnas in Australia (McKemey et al. 2019), medicinal plants in French Guiana (Tareau et al. 2020), and herring on the Pacific coast of North America (Moss 2016). Modifications of the original concept have included combining it with the concept of biocultural diversity, arguing that Biocultural Keystone Species better captures the diverse range of ecological and cultural significance such species often hold (Shackleton et al. 2018). It has also been expanded to things beyond the level of "species" such as Cultural Keystone Places (Cuerrier et al. 2015) and Cultural Keystone Food Groups (Taylor and Anderson 2020). Recent critiques of the concept have pointed out that, until now, it has been applied in a largely qualitative fashion and little has been done to further revise the metrics originally proposed in Garibaldi and Turner (2004) (Coe and Gaoue 2020a, 2020b).

In light of the continuing utility of the Cultural Keystone Species concept, we propose a refinement of the term that better captures the cultural centrality of Ceiba pentandra and related species - Spiritual Keystone Species. As their essential nature is immaterial, Spiritual Keystone Species do not need to aid in resource acquisition, so this criterion is discarded. Given the exchanges and correlations of practices between different cultures around different Bombacoideae species, the criteria of irreplaceability is also discarded. Indeed, Ceiba pentandra is one (the pre-eminent, but still only one) of numerous species that can host different kinds of spirits in many Neotropical ontologies; the mutability of identity of the "Ceiba tree" is related to the fact that the spirits inhabiting it can themselves inhabit other trees or beings. It is possible that Spiritual Keystone Species, as opposed to Cultural Keystone Species, are actually more likely to morph over time as the same unit of cultural meaning becomes applied to different species that share the same spiritual qualities. Instead of the criteria of irreplaceability and resource acquisition, we propose the adoption of two new criteria: the presence of culturally derived beliefs, rules, or taboos that regulate contact with the species; and the attribution of magical efficacy or the ability to mediate between humans and spirits, deities, or divine realms.

The Bombacoideae trees are an excellent example of Spiritual Keystone Species given their widespread centrality in spiritual practices and the presence of numerous taboos against cutting or injuring them. Another classic example of a Spiritual Keystone Species is Ficus religiosa L. (and related species), which is similarly protected by taboos against cutting it down and is sacred to Buddhists as the Bodhi Tree, under which Buddha attained enlightenment, and to Hindus as a manifestation of Vishnu (Jain and Kapoor 2007). The baobabs in Africa (Adansonia spp.) (Marie et al.2009), the ash (Dumont 1992) and the yew in Europe (Hageneder 2015; Hooke 2012), and Araucaria spp. in Chile (Herrmann 2006) are further examples of trees that are Spiritual Keystone Species, whereas the jaguar (Panthera onca) in Amazonia (Shepard 2014), the Asian elephant (Elephas maximus) in south and southeast Asia (Ramanathapillai 2009), and the reindeer (Rangifer tarandus) in Siberia 
(Vitebsky and Alekseyev 2015) could be considered examples of animals that are Spiritual Keystone Species.

It is important to note that although there are often many sacred species (Pungetti 2012) that likely fulfill some of the criteria laid out here, only a few of these species generally meet all the criteria and thus constitute true Spiritual Keystone Species. There are also important differences with "sacred trees" and "sacred groves" because individual trees are sometimes considered sacred while the species to which they belong is not. Perhaps the most striking difference between the Spiritual Keystone Species approach and other conceptions of Keystone Species is that the sacred species is in fact an ethnospecies and the mutability of its application to different Linnean species is a significant indicator of its immaterial cultural function. An excellent example of this mutability is the use of both silver sage (Salvia argentea L.) and the botanically unrelated sagebrush (Artemisia spp.) as purifying plants falling under the same common conceptual category of "sage", a potential Spiritual Keystone Species in parts of North America (Paldam 2018).

\section{Conclusion}

Although much had been said in anthropological and (or) ethnobiological monographs about Ceiba spp. in the Neotropics, a comprehensive review has been lacking. This review provides an understanding of the central place that Ceiba pentandra and associated species share through most of the cosmovisions from the cultural groups present in their distribution range. Axis mundi, related with water and water spirits, psychopomp, or associated to shamanistic practices - these aspects are all much related to the spiritual realm. If this can be explained by particular traits such as its incredible size, rapid growth, conspicuous thorns, seasonal defoliation pattern, and bat pollination, the fact that this tree's perception is shared by so many cultures including Indigenous, Afro-descendant, and West African, is uncommon. Spiritual Keystone Species such as Ceiba pentandra are likely to be culturally specific, but this one stands as a common thread for almost all Neotropical and Caribbean cultures, making it probably the most emblematic species of its range. The concept of Spiritual Keystone Species needs to be further explored and refined, notably through a worldwide review of what species fall within its definition.

\section{Acknowledgements}

This work was funded by "Investissement d'Avenir" grants managed by the Agence Nationale de la Recherche (Labex DRIIHM/IRDHEI: ANR-11-LABX-0010 and Labex CEBA: ANR-10-LABX-25-01) and by the Prime80-DiaspoREs projects from the CNRS "Mission pour l'Interdisciplinarité et les Initiatives Transverses".

\section{References}

Ahlbrinck, W. 1931. Encyclopaedie der Karaïben. In Institut Géographique National. ed. Verhondelingen der Köninklijke Akademie von wetenschappen, Amsterdam. Traduction française. Paris.

Albert, B., and Miliken, W. 2009. Urihi a: a terra-floresta Yanomami. ISA-IRD. São Paulo.

Alexiades, M. 1999. Ethnobotany of the Ese Eja: plants, health, and change in an Amazonian society. Ph.D. thesis, City University of New York.

Anderson, K. 1997. Nature, culture and big old trees: human relationships with Ceiba (Ceiba pentandra) and Live Oak (Quercus virginiana) in the landscapes of Guatemala and Louisiana. LSU historical dissertations and theses, 6379, Louisiana State University.

Balée, W. 1994. Footprints of the forest, Ka'apor ethnobotany: the historical ecology of plant utilization by an Amazonian people. Columbia University Press, New York.

Bennett, B.C., Baker, M.A., and Andrade, P.G. 2002. Ethnobotany of the Shuar of Eastern Ecuador: Advances in Economic Botany, Vol. 14. New York Botanical Garden.

Benoît, C. 2000. Corps, jardin, mémoires, Anthropologie du corps et de l'espace à la Guadelope. CNRS Editions/Editions de la maison des sciences de l'Homme, France.

Berlin, B. 1993. Ethnobiological classification: principles of categorization of plants and animals in traditional societies. Princeton University Press.

Bernand, C. 2019. Histoire des peuples d'Amérique. Fayard, France.

Bougerol, C. 1993. Le cumul magico-religieux à la Guadeloupe. Journal de la Société des Américanistes, 79: 91-103. doi:10.3406/jsa.1993.1470.

Bowen-Jones, E., and Entwistle, A. 2002. Identifying appropriate flagship species: The importance of culture and local contexts. Oryx, 36: 189-195. doi:10.1017/S0030605302000261.

Boyle, B., Hopkins, N., Lu, Z., Raygoza Garay, J.A., Mozzherin, D., Rees, T., et al. 2013. The taxonomic name resolution service: an online tool for automated standardization of plant names. BMC Bioinform. 14: 16. doi:10.1186/1471-2105-14-16.

Breton, R.P. 1665. Dictionnaire caraïbe français. IRD-Karthala éditions, Paris.

Burkill, H.M. 1995. The useful plants of west tropical Africa, Vols. 1-3. Royal Botanic Gardens, Kew.

Cabrera, L. 2003. La Forêt et les Dieux. Religions afrocubaines et médecine sacrée à Cuba. Jean Michel Place éditions, France.

Cano, L.M., and Hellmuth, N.M. 2008. Sacred tree: Ceiba. Mayan Ethnobotany, Asociacion FLAAR, Mesoamerica.

Chapuis, J., and Rivière, H. 2003. Wayana eitoponpë: (une) histoire (orale) des indiens Wayana. Ibis Rouge éditions, Guyane.

Chauhan, S., and Chauhan, S.V.S. 2019. Worship and trees in India. Siberian For. J. 4: 36-48. doi:10.15372/sjfs20190404.

Chaumeil, J.-P. 2000. Voir, savoir, pouvoir, le chamanisme chez les Yagua de l'Amazonie péruvienne. Georg éditions, Genève.

Childs, D. 2012. A study of religion, culture, and medicinal plants of three South American Indigenous groups. Ph.D. thesis, University of Delaware.

Clark, D., Artelle, K., Darimont, C., Housty, W., Tallio, C., Neasloss, D., et al. 2021. Grizzly and polar bears as nonconsumptive cultural keystone species. FACETS, 6: 379393. doi:10.1139/facets-2020-0089.

Coe, F.G., and Anderson, G.J. 1999. Ethnobotany of the Sumu (Ulwa) of southeastern Nicaragua and comparisons with Miskitu plant lore. Econ. Bot. 53: 363-386. doi:10.1007| BF02866715. 
Coe, M.A., and Gaoue, O.G. 2020a. Cultural keystone species revisited: are we asking the right questions? J. Ethnobiol. Ethnomed. 16(1): 11. doi:10.1186/s13002-020-00422-z.

Coe, M.A., and Gaoue, O.G. 2020b. Most cultural importance indices do not predict species' Cultural Keystone Status. Hum. Ecol. 48: 721-732. doi:10.1007/s10745-020-00192-y.

Corzani, J. 1994. West Indian mythology and its literary illustrations. Res. Afr. Literatures, 25: 131-139.

Couplan, F. 2000. Dictionnaire étymologique de botanique: comprendre facilement tous les noms scientifiques, La bibliothèque du naturaliste. Delachaux et Niestlé éditions, Lausanne.

Cuerrier, A.A., Turner, N.J., Gomes, T.C., Garibaldi, A., and Downing, A. 2015. Cultural Keystone places: conservation and restoration in cultural landscapes. J. Ethnobiol. 35: 427-448. doi:10.2993/0278-0771-35.3.427.

Dance, C.D. 1881. Chapters from a Guianese log-book, or the folk-lore and scenes of sea-coast and river life in British Guiana; comprising sketches of Indian, Boviander, and Negro life. The Royal Gazette, Guyana.

Davis, W.E., and Yost, J.A. 1983. The ethnobotany of the Waorani of Eastern Ecuador. Botanical Museum Leaflets, Harvard Univ. 29: 159-217.

De Feo, V. 1992. Medicinal and magical plants in the northern Peruvian Andes. Fitoterapia, 63 (5): 417-440.

de Goeje, C.H. 1943. Philosophy, initiation and myths of Indians of Guiana and adjacent countries. International archiv für Ethnographie.

Delascio-Chitty, F.D. 1985. Algunas plantas usadas en la medicina empírica venezolana. Direccion de Investigaciones BiologicasDivision de Vegetación-Jardin Botánico-Inparques, Caracas.

Descola, P. 1996. La nature domestique symbolisme et praxis dans l'écologie des Achuar. Maison des Sciences de l'Homme, Paris.

Descola, P. 2005. Par-delà nature et culture, Bibliothèque des sciences humaines. Gallimard, Paris.

DeWalt, S.J., Bourdy, G., Chávez de Michel, L.R., and Quenevo, C. 1999. Ethnobotany of the Tacana: Quantitative inventories of two permanent plots of Northwestern Bolivia. Econ. Bot. 53: 237-260. doi:10.1007/BF02866635.

Dick, C.W., Bermingham, E., Lemes, M.R., and Gribel, R. 2007. Extreme long-distance dispersal of the lowland tropical rainforest tree Ceiba pentandra L. (Malvaceae) in Africa and the Neotropics. Mol. Ecol. 16: 3039-3049. doi:10.1111/ j.1365-294X.2007.03341.x. PMID:17614916.

Duin, R. 2009. Wayana socio-political landscapes: multiscalar regionality and temporality in Guiana. Ph.D. thesis, University of Florida.

Dumont, D.J. 1992. The ash tree in Indo-European culture. Mankind Q. 32: 323-336. doi:10.46469/mq.1992.32.4.1.

Durand, G., and Logossah, K. 2011. Les noms de famille d'origine africaine de la population martiniquaise d'ascendance servile: et autres survivances africaines en Martinique (seconde édition revue et enrichie). Editions L'Harmattan, France.

Eliade, M. 1958. Patterns in comparative religion, University of Nebraska Press, London. doi:10.2307/3709402.

Erikson, P. 1996. La griffe des aïeux: marquage du corps et démarquages ethniques chez les Matis d'Amazonie, Langues et sociétés d'Amérique traditionelle. Peeters, Paris.

Erikson, P. 2014. El ritual como máquina del tiempo: ejemplos chacobo (Amazonía boliviana). In Antes de Orellana-Actas Del 3er Encuentro Internacional de Arqueología Amazónica. Edited by S. Rostain. Lima. pp. 399-406.

Filipov, A. 1994. Medicinal plants of the Pilagá of Central Chaco. J. Ethnopharmacol. 44(3): 181-193. doi:10.1016/03788741(94)01185-0. PMID:7898125.
Fleury, M. 1991. Busi-Nenge, les hommes-forêt: Essai d'ethnobotanique chez les Aluku (Boni) en Guyane française. Thèse de doctorat, Paris, 6 .

Fowler, C.T. 2003. The ecological implications of ancesral religion and reciprocal exchange in a sacred forestin Karendi (Sumba, Indonesia). Worldviews, 7: 303-329. doi:10.1163/156853503322709155.

Freidel, D.A., Schele, L., and Parker, J. 1993. Maya Cosmos: three thousand years on the shaman's path. Harper and Collins, New York.

Garibaldi, A., and Turner, N. 2004. Cultural keystone species: implications for ecological conservation and restoration. Ecol. Soc. 9(3): 1. doi:10.5751/ES-00669-090301.

Gentry, A.H., and Vasquez, R. 1988. Where have all the Ceibas gone? A case history of mismanagement of a tropical forest resource. For. Ecol. Manage. 23: 73-76. doi:10.1016/ 0378-1127(88)90015-1.

Gillin, J.P. 1936. The Barama River Caribs of British Guiana. Paper of the Peabody Museum of Archeology and Ethnology $\mathrm{N}^{\circ} 14$.

Gillin, J.P. 2014. Cuerpos en transformación: sobre la noción de persona y el control alimentar entre los Yaminawa. Tellus, 10(19): 53-82. doi:10.20435/tellus.v0i19.215.

Giovannini, P. 2015. Medicinal plants of the Achuar (Jivaro) of Amazonian Ecuador: Ethnobotanical survey and comparison with other Amazonian pharmacopoeias. J. Ethnopharmacol. 164: 78-88. doi:10.1016/j.jep.2015.01.038. PMID:25660382.

Girault, L. 1984. Kallawaya, guérisseurs itinérants des Andes: recherches sur les pratiques médicinales et magiques. IRD Editions, France.

Gomez Gruber, J. (Editor). 1997. O livro das arvóres. Organização Geral dos Professores Ticuna Bilíngües. Benjamin Constant.

Grenand, F. 1989. Dictionnaire wayãpi-français: lexique françaiswayãpi ; (Guyane française), Langues et sociétés d'Amérique traditionnelle. Peeters, Paris.

Grenand, P. 1980. Introduction à l'étude de l'univers Wayapi : ethnoécologie des Indiens du Haut-Oyapock (Guyane française), Langues et Civilisations à Tradition Orale. SELAF, Paris.

Grenand, P., Moretti, C., Jacquemin, H., and Prévost, M.-F. 2004. Pharmacopées traditionnelles en Guyane: Créoles, Palikur, Wayãpi. IRD/Orstom éditions, Paris.

Gribel, R., Gibbs, P.E., and Queiróz, A.L. 1999. Flowering phenology and pollination biology of Ceiba pentandra (Bombacaceae) in Central Amazonia. J. Trop. Ecol. 15(3): 247-263. doi:10.1017/S0266467499000796.

Hageneder, F. 2015. Ancient trees and their social recognition: Taxus baccata L. Yew and ancient kingship rituals European traditions and their Anatolian roots. In The 1st International Yew Workshop of Turkey in Duzce, 2007. pp. 39-49.

Herrmann, T.M. 2006. Indigenous knowledge and management of Araucaria araucana forest in the Chilean Andes: implications for native forest conservation. Biodivers. Conserv. 15: 647-662. doi:10.1007/s10531-005-2092-6.

Herskovits, M.J., and Herskovits, F.S. 1936. Suriname folklore. DBNL.

Hodge, W.H., and Taylor, D. 1957. The ethnobotany of the island Caribs of Dominica. Webbia, 12: 513-644. doi:10.1080/ 00837792.1957 .10669669$.

Hooke, D. 2012. The sacred tree in the belief and mythology of England. In Sacred species and sites. Edited by G. Pungetti, G. Oviedo, and D. Hooke. Cambridge University Press. pp. 307321. doi:10.1017/CBO9781139030717.030.

Hurbon, L. 1940-1972. Dieu dans le Vaudou haitien. Bibliothèque scientifique, Payot, France. 
Jain, S.K., and Kapoor, S.L. 2007. Divine botany-universal and useful but under explored traditions. Ind. J. Trad. Knowl. 6: 534-539.

Jain, V., Verma, S.K., and Katewa, S.S. 2009. Myths, traditions and fate of multipurpose Bombax ceiba L. - An appraisal. Ind. J. Trad. Knowl. 8: 638-644.

Jamieson, M. 1970. Contratos con los dawanka y procesos productivos entre los miskitos de las comunidades costeras de la RAAS. Wani, 56: 15-24. doi:10.5377/wani.v56i0.222.

Jones, O., and Cloke, P. 2008. Non-human agencies: trees in place and time. In Material agency: towards a non-anthropocentric approach. Edited by C. Knappett and L. Malafouris. Springer. pp. 79-96. doi:10.1007/978-0-387-74711-8_5.

Keegan, W.F., and Carlson, L.A. 2008. Talking Taíno: Caribbean natural history from a native perspective. University of Alabama Press, USA.

Langdon, E.J. 2014. La negociación de lo oculto: chamanismo, medicina y familia entre los Siona del bajo Putumayo. Editorial Universidad del Cauca, Popayán.

Lentz, D.L. 1993. Medicinal and other economic plants of the Paya of Honduras. Econ. Bot. 47: 358-370. doi:10.1007| BF02907349.

Leti, G. 2000. L'univers magico-religieux antillais: ABC des croyances et superstitions d'hier et d'aujourd'hui. Editions L'Harmattan, France.

Lévi-Strauss, C. 2009. Du miel aux cendres, Mythologiques. Plon, Paris.

Lobo, J.A., Quesada, M., and Stoner, K.E. 2005. Effects of pollination by bats on the mating system of Ceiba pentandra (Bombacaceae) populations in two tropical life zones in Costa Rica. Am. J. Bot. 92: 370-376. doi:10.3732/ajb.92.2.370. PMID:21652412.

Luna, L.E. 1986. Vegetalismo: shamanism among the mestizo population of the Peruvian Amazon. Stockholm Studies in Comparative Religion, Stockholm.

Mahecha, D., and Franky, C. 2013. Recolectando en el Cielo: elementos del manejo nfkak del mundo (amazonia Colombiana). Digital edition available on the website of the Programa de Pós-Graduação em Antropologia Social. Museu Nacional/UFRJ. Rio de Janeiro.

Mansutti Rodríguez, A. 2019. Warime Piaroa: cuatro performances en un rito. Rev. Colombiana Antropol. 55: 149167. doi:10.22380/2539472X.803.

Marcelin, É., and Métraux, A. 1947. Les grands dieux du vodou haïtien. J. Soc. Am. 36: 51-135. doi:10.3406/jsa.1947.2357.

Marie, C.N., Sibelet, N., Dulcire, M., Rafalimaro, M., Danthu, P., and Carrière, S.M. 2009. Taking into account local practices and indigenous knowledge in an emergency conservation context in Madagascar. Biodivers. Conserv. 18: 2759-2777. doi:10.1007/s10531-009-9672-9.

Matarezio Filho, E.T. 2015. Trompetas ticuna de la Fiesta de la Moça Nova. In: Mundos Audibles de América: Cosmologías y Prácticas Sonoras de Los Pueblos Indígenas. Edited by B. Brabec de Mori, M. Lewy, and M.A. García. Berlin. pp. 121135.

McKemey, M.B., Patterson, M. (Leslie), Rangers, B., Ens, E.J., Reid, N.C.H., Hunter, J.T., et al. 2019. Cross-cultural monitoring of a Cultural Keystone Species informs revival of Indigenous burning of country in south-eastern Australia. Hum. Ecol. 47: 893-904. doi:10.1007/s10745-019-00120-9.

Moomou, J. 2013. Les Marrons Boni de Guyane. Ibis Rouge Editions, Matoury.

Mori, S.A., Cremers, G., Gracie, C., de Granville, J.-J., Heald, S.V., Hoff, M., and Mitchell, J.D. 2002. Guide to the vascular plants of central French Guiana: Part 2. Dicotyledons, Memoirs of the New York botanical garden. New York Botanical Garden Press, New York.
Moss, M.L. 2016. The nutritional value of Pacific herring: An ancient cultural keystone species on the Northwest Coast of North America. J. Archaeol. Sci. Rep. 5: 649-655. doi:10.1016/ j.jasrep.2015.08.041.

Navet, E. 2008. Savoirs communs et chamaniques sur les plantes médicinales et psychotropes des Indiens Teko (Emérillon) de Guyane.

Nossin, E. 2019. Plantes magiques de Martinique, Guadeloupe et des Petites Antilles Emmanuel Nossin, André Exbrayat. Exbrayat éditions, France.

Odonne, G., Berger, F., Stien, D., Grenand, P., and Bourdy, G. 2011. Treatment of leishmaniasis in the Oyapock basin (French Guiana): A K.A.P. survey and analysis of the evolution of phytotherapy knowledge amongst Wayãpi Indians. J. Ethnopharmacol. 137: 1228-1239. doi:10.1016/j.jep.2011.07.044. PMID:21816216.

Ouensanga, C. 1983. Plantes médicinales et remèdes creoles. Tome I. Editions Désormeaux, France.

Paine, R.T. 1969. A note on trophic complexity and community stability. Am. Nat. 103: 91-93. doi:10.1086/282586.

Paldam, E. 2018. White sage, bears, and territory: contemporary indigenous religion among the Chumash. J. Contemp. Relig. 33: 467-486. doi:10.1080/13537903.2018.1535374.

Pérez, P. 2005. Petite encyclopédie maya: l'environnement des Lacandons de Lacanjá (Chiapas, Mexique), Recherches Amériques latines. L'Harmattan éditions, Paris.

Pesoutova, J. 2019. Indigenous ancestors and healing landscapes: cultural memory and intercultural communication in the Dominican Republic and Cuba. Ph.D. thesis, Leiden University, the Netherlands. Available from https:// openaccess.leidenuniv.nl/handle/1887/68891 [accessed 25 March 2019].

Pezzini, F.F., Dexter, K.G., de Carvalho-Sobrinho, J.G., Kidner, C.A., Nicholls, J.A., de Queiroz, L.P., and Pennington, R.T. 2021. Phylogeny and biogeography of Ceiba Mill. (Malvaceae, Bombacoideae). Front. Biogeogr. 13(2): e49226. doi:10.21425/ F5FBG49226.

Pio Correa, M. 1984. Dicionário das plantas úteis do Brasil. IBDF, Brasilia.

Platten, S., and Henfrey, T. 2009. The cultural keystone concept: Insights from ecological anthropology. Hum. Ecol. 37: 491500. doi:10.1007/s10745-009-9237-2.

Pollak-Eltz, A. 1972. Vestigios africanos en la cultura del pueblo venezolano. Universidad Católica Andrés Bello, Instituto de Investigaciones Históricas.

Price, R., and Mintz, S.W. 2013. The birth of African-American culture. In African-American Religion. Routledge. pp. 46-62.

Pungetti, G. 2012. Sacred species and sites: dichotomies, concepts and new directions in biocultural diversity conservation. In Sacred species and sites. Edited by G. Pungetti, G. Oviedo, and D. Hooke. Cambridge University Press. pp. 13-27. doi:10.1017| CBO9781139030717.005.

Quiroz, D. 2015. Do not fear the supernatural!: The relevance of ritual plant use for traditional culture, nature conservation, and human health in western Africa. Ph.D. thesis, Wageningen University.

Quiroz, D., and van Andel, T. 2018. The cultural importance of plants in Western African religions. Econ. Bot. 72: 251262. doi:10.1007/s12231-018-9410-x. PMID:30573919.

Ramanathapillai, R. 2009. A forest ride on wild elephants: the philosophy of wilderness in Buddhism. Gajah, 30: 29-33.

Rashford, J. 1985. The cotton tree and the spiritual realm in Jamaica. Jamaica J. 18: 49-57.

Reichel-Dolmatoff, G. 1975. Templos kogi. Rev. Colomb. Antropol. 19: 199-245. doi:10.22380/2539472X.1670.

Renshaw, J. 2006. The effectiveness of symbols" Revisited: Ayoreo Curing Songs. Tipití: Journal of the Society for the Anthropology of Lowland South America, 4(1): 12. 
Reyes-García, V. 2001. Indigenous people, ethnobotanical knowledge, and market economy. A case study of the tsimane' amerindians in lowland Bolivia. Ph.D. thesis, University of Florida.

Ribal-Rilos, M.M. 2004. Plantes et pratiques magico religieuses aux Antilles et en Guyane. Conférence Inaugurale de l'UAO-UTL.

Rival, L. 1999. Trees and the symbolism of life in indigenous cosmologies. In Cultural and spiritual values of biodiversity. Edited by D. Posey. UNEP, Nairobi. pp. 358-362.

Roe, P.G. 1982. The cosmic zygote: cosmology in the Amazon Basin. Rutgers University Press, New Brunswick, New Jersey.

Roth, W.E. 1915. An inquiry into the animism and the folklore of the Guiana Indians. Annual report of the Bureau of American Ethnology to the Secretary of the Smithsonian Institution 1908-1909, v. 30, pt. 2. Smithsonian Institution, Washington, D.C. pp. 103-386.

Roumy, V., Ruiz Macedo, J.C., Bonneau, N., Samaillie, J., Azaroual, N., Encinas, L.A., et al. 2020. Plant therapy in the Peruvian Amazon (Loreto) in case of infectious diseases and its antimicrobial evaluation. J. Ethnopharmacol. 249: 112411. doi:10.1016/j.jep.2019.112411. PMID:31751651.

Saavedra, C. 2006. Estudio de la adaptación del chamanismo shipibo-conibo al medio urbano: el caso de Guillermo Arévalo en la ciudad de Pucallpa. Ph.D. thesis, Université de Montréal.

Sahlins, M. 2019. On the political economy of the enchanted universe. In Au Seuil de La Forêt : Hommage à Philippe Descola, l'anthropologue de La Nature. Edited by G. Cometti, P. Le Roux, T. Manicone, and N. Martin. Mirebeau-sur-Bèze, pp. 911-952.

Scarpa, G.F. 2007. Plantas asociadas a la pesca y a sus recursos por los Indígenas Chorote del Chaco Semiarido (Argentina). Bol Soc Argentina Bot. 41(3-4): 333-345.

Schele, L., and Freidel, D.A. 1990. A forest of kings: the untold story of the Ancient Maya. William Morrow, USA.

Sequera, G., and Gangui, A. 2011. The Tomárâho conception of the sky. Proc. Int. Astronom. Union, 7(S278): 65-73. doi:10.1017| S1743921311012488.

Séverin, F. 2002. Plant ak pyebwa tè d Ayiti. Quitel éditions. Port-au-Prince.

Shackleton, C.M., Ticktin, T., and Cunningham, A.B. 2018. Non-timber forest products as ecological and biocultural keystone species. Ecol. Soc. 23(4): 22. doi:10.5751/ES-10469230422.

Shearn, I. 2020. Canoe societies in the Caribbean: Ethnography, archaeology, and ecology of precolonial canoe manufacturing and voyaging. J. Anthropol. Archaeol. 57: 101140. doi:10.1016/j.jaa.2019.101140.

Shepard, G. 2014. Old and in the way: Jaguar transformation in Matsigenka. South Peru Panel View Project Sign, Substance, and Sensation: A Sensory Ecology of Shamanic Plants in Indigenous Amazonia View Project.

Silva, M.F., Braga Lisbôa, P.L., and Lobato Lisbôa, R.C. 1977. Nomes vulgares de plantas amazônicas. INPA, Manaus.

Small, W., and Small, K. 2003. The sacred silk-cotton tree: an investigation into the folklore, origins, biology and distribution of the silk-cotton tree. W. Small.

Tareau, M.-A. 2019. Les phytothérapies du littoral guyanais : regard ethnobotanique sur une pharmacopée métissée. Ph.D. thesis, Université de Guyane.

Tareau, M.-A., Bonnefond, A., Palisse, M., and Odonne, G. 2020. Phytotherapies in motion: French Guiana as a case study for cross-cultural ethnobotanical hybridization. J. Ethnobiol. Ethnomed. 16(1): 18. doi:10.1186/s13002-020-00404-1.

Tarter, A. 2015. Trees in Vodou: An arbori-cultural exploration. J. Study Religion Nat. Cult. 9(1): 87-112. doi:10.1558/ jsrnc.v9i1.19582.

Taylor, D.W., and Anderson, G.J. 2020. Culinary cultural conservation and cultural keystone food groups: concepts in ethnobotany. Hum. Ecol. 48: 189-198. doi:10.1007/s10745020-00137-5.

Ter Steege, H., Vaessen, R.W., Cárdenas-López, D., Sabatier, D., Antonelli, A., De Oliveira, S.M., et al. 2016. The discovery of the Amazonian tree flora with an updated checklist of all known tree taxa. Sci. Rep. 6: 29549. doi:10.1038/srep29549. PMID:27406027.

The Angiosperm Phylogeny Group. 2016. An update of the Angiosperm Phylogeny Group classification for the orders and families of flowering plants: APG IV. Bot. J. Linn. Soc. 181: 1-20. doi:10.1111/boj.12385.

Tournon, J. 1990. Magia, brujería, chamanismo, plantas y enfermedades. Rev Anthropol. Dep. Ciencias Soc. 8: 175192.

Tozzer, A.M. 1907. A comparative study of the Mayas and the Lacandones. Archaeological Institute of America, USA.

van Andel, T. 2000. Non-timber forest products of the NorthWest district of Guyana. Tropenbos-Guyana Programme. Utrecht.

van Andel, T. 2010. How African-based Winti belief helps to protect forests in Suriname. In Sacred natural sites: conserving nature and culture. Edited by B. Verschurren, R. Wild, J. McNeely, and G. Oviedo. Earthsca, London. pp. 139-145.

van Andel, T., and Ruysschaert, S. 2014. Medicinale en rituele planten van Suriname. LM Publishers.

van Andel, T., Ruysschaert, S., de. Putte, K.V., and Groenendijk, S. 2013. What makes a plant magical? Symbolism and sacred herbs in Afro-Surinamese Winti rituals. In African ethnobotany in the Americas. Edited by R. Voeks, and J. Rashford. Springer, New York. pp. 247-284. doi:10.1007/978-1-46140836-9_10.

Verschuur, G. 1894. Voyage aux trois Guyanes et aux Antilles. Hachette et cie. France.

Vickers, W.T., and Plowman, T. 1984. Useful plants of the Siona and Secoya Indians of Eastern Ecuador. Field Museum of Natural History, Botany, Chicago, Ill.

Vilayleck, E. 2002. Ethnobotanique et médecine traditionnelle créoles. Ibis Rouge Editions, Martinique.

Vitebsky, P., and Alekseyev, A. 2015. What is a reindeer? Indigenous perspectives from northeast Siberia. Polar Record, 51: 413-421. doi:10.1017/S0032247414000333.

Wright, R.M. 2020. A Joyful Place: Baniwa Jaguar shamans' songs and historical change. doi:10.13140/RG.2.2.34124.44167.

Zapico, F., Dizon, J., Fernando, E., Borromeo, T., McNally, K., and Hernandez, J. 2020. Upland rice: cultural keystone species in a Philippine traditional agroecosystem. Asian J. Agric. Dev. 17: 93-105. doi:10.37801/ajad2020.17.2.6.

Zeven, A.C. 1969. Kapok tree (Ceiba pentandra Gaertn.). In Outlines of perennial crop breeding in the Tropics, Miscellaneous Papers 4. Edited by F.P. Ferwerda and F. Wit. Veenman, the Netherlands, pp. 269-288.

Zidar, C., and Elisens, W. 2009. Sacred Giants: Depiction of Bombacoideae on Maya Ceramics in Mexico, Guatemala, and Belize. Econ. Bot. 63: 119-129. doi:10.1007/s12231-0099079-2. 